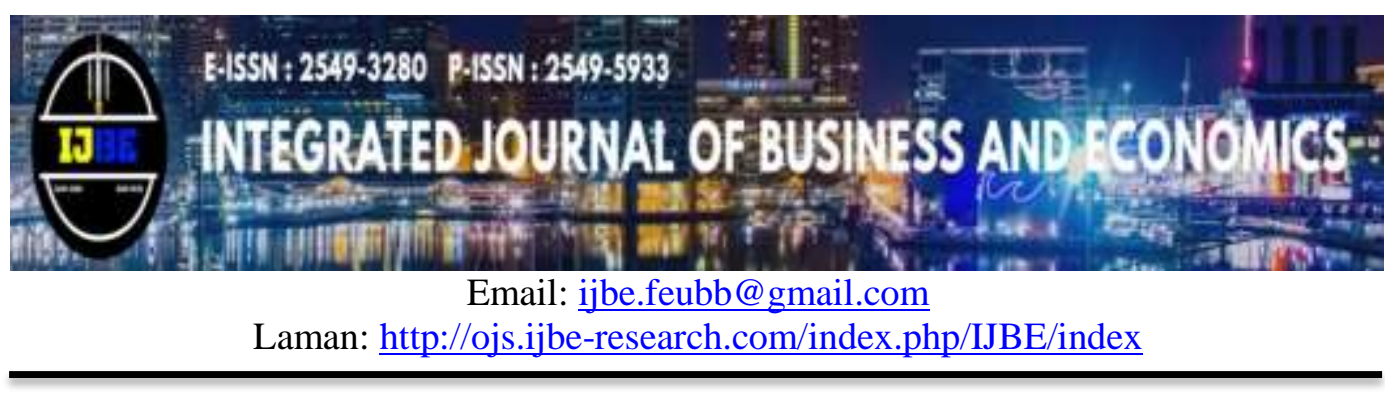

\title{
Factors Influencing The Income Of Fishermen
}

\author{
Aning Kesuma Putri ${ }^{\mathrm{a}}$, Ayu Wulandari ${ }^{\mathrm{b}}$ \\ ${ }^{a, b}$ Universitas Bangka Belitung, Indonesia \\ putrianing@gmail.com, awulandari0908@gmail.com
}

\begin{abstract}
The purpose of this research was to determine the variability of fishermen's incomes by looking at the effect of fishermen's experience, fishermen's education, and fisherman's working hours on income. The population of this research is fishermen in East Belitung Regency with a sample of 181 people and Central Bangka Regency as many as 57 people. The method is carried out through quantitative analysis using path analysis, with primary data in the form of interviews and questionnaires to fishermen. The results showed that the variables of fishermen's experience and working hours had a significant effect on the variability of fishermen's income, as evidenced by the probability of significance at 0,000 (below 0.05) and F-count, t-count is greater than F-table, t-table. While education is not a factor of variability in fishermen's income because the results of the F-count, $t$-count is smaller than the F-table, $t$-table. Future research should measure the variability of fishermen's incomes using variables of the level of fish production, the amount of credit or debit, side income, and poverty of fishermen, using Micmac and Mactor method.
\end{abstract}

\section{Article Info}

- Received : June 15, 2020

- Revised : June 22, 2020

- Published : June 26, 2020

- No. Pages : 198 - 210

- DOI : 10.33019/ijbe.v4i2.298

- JEL : D33, E25

- Keywords : Fishermen's, Income, Path Analysis 


\section{Introduction}

The instability of fishermen's revenues resulted in fishermen being in a povertyswirl, and the revenue affected by 1 percent (Juariyah, 2010) (Triyanti dan Maulana, 2016). The results of the study Putri et al. (2018) found that the cause of the income of the fishermen not able to provide welfare because fishing patterns of fishermen aged 18-42 years on average of IDR 1.5 million and the highest expenditure intended for smoking, compared to children's education needs and family health.

Climate change impacts fishermen's revenues as it affects fishing operations, resulting in fishermen experiencing changes in other business activities such as labor and trade, which deemed able to meet the extra income of fishermen (Vibriyanti, 2019). The other factors affecting the revenue of fishermen are the capture distance, working hours, the rain dummy, and the wave, causing vulnerable fishermen households in the search for other livelihoods (Azizi et al., 2017).

This research will focus on examining the variability of fishermen's incomes in East Belitung and central Bangka because of the number of fishermen in both regions in Bangka Belitung province. The cause of income variability in the area is caused by various factors, including the experience and education of fishermen (Pratama et al., 2012).

The income level affects the welfare of the fishermen's households. Some research found that the value of fishermen's livelihoods categorized enough, due to high food and non-food consumption indicators, and the social capital of fishermen have a poor category. Low social capital caused by the dependency of fishermen's with the middleman, so that the access of fishermen's on economic institutional and social institutions are weak (Triyanti, 2016). Others have found that factors that have a significant effect on statistically-incomes are the education of fishermen, the experience of the sea, and the power of machinery, while the factors affecting the chances of poverty of fishermen are the age of fishermen, the education of fishermen as the head of the family, and the experience of the sea (Primyastanto et al., 2012). Then what about the fishermen's income capacity at the research site, the average income can be seen in figure 1.

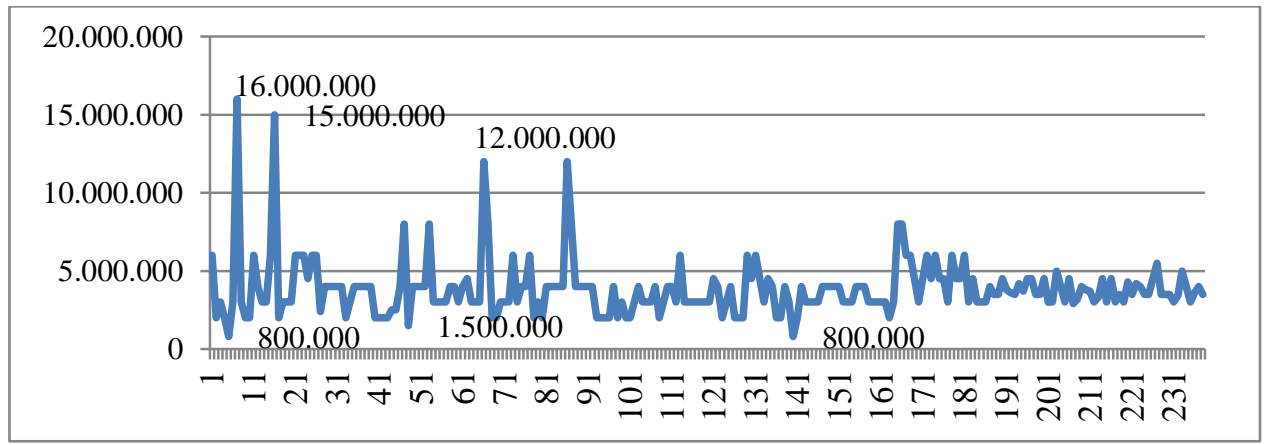

Source: Data processed, 2019

Figure 1. Average household income of fishermen in East Belitung District and Central Bangka District 
The highest income obtained by fishermen amounted to IDR 16 million while the lowest of IDR 800,000 with an average total of IDR 5,061,945. The high-income fishermen are located in East Belitung Regency, while the low-income fishermen are fishermen in Bangka Tengah district. Fishermen's Central Bangka District is more vulnerable than fishermen's East Belitung district because of natural factors, climate change causes weather patterns to change, the season of famine become longer, often occurs extreme weather that is a nipple wind, and not supported by capture technology that can resist weather pressure, causing income decrease. An alternative business that fishermen do to increase revenue is working at mining lead, gardening, entrepreneurship, and trying other businesses (Marfirani \& Adiatma, 2012) (Pratama et al., 2012).

The catch of fish is then sold to the market either directly by fishermen or through middleman brokers, determining the income level of fishermen (Rahmawati, 2017). Dahen's (2016) research found that the capital, working hours, and work experience of fishermen in Aceh influenced the fishermen's income. While the research results of Esa and Putra (2016) argue that the experience of the sea, long ago, operational costs and amount do not affect the income of fishermen in the village Batununggul of Bali Province. The results of Rahim's (2017) research found that the income of motorboat fishermen on the coast of South Sulawesi was positively influenced by our kerosene and the productivity of the capture business but negatively related to gasoline prices, long oversea, travel and differences in the area of capture.

So based on the background described earlier, the research was conducted to see the variability of fishermen's incomes in East Belitung and central Bangka district by using variable improving fishermen, education fishermen, and working hours.

\section{Literature Review}

\section{Income Theory}

Income is the amount of income received by members of the community for a while in return for the services or the factors of the donated production. Revenues defined as the income received by the population for their performance over a while, either, on their performance for a certain period, daily, weekly, monthly, or yearly. The income classification is as follows (Azizi et al., 2017):

1. Personal income is all types of income acquired without giving any activity that a resident of a Contracting State receives.

2. Disposable income is a personal income tax-deductible to paid by the beneficiaries, the remaining income that is ready to spend called disposable income.

3. National income is the value of all finished goods and services that profiled by the state in one year.

If connected with the theory of income, the revenue of fishermen's is the difference between the acceptance (total revenue) with all the cost (total cost) incurred, so that the formula as follows (Ioan et al., 2015) (Nurprihatin \& Tannady, 2017): Yn = TR- TC. 
The indicator of the fishermen's acceptance (total revenue) obtained through multiplication between production (Y) and the selling price (Py). While the cost of fishermen consists of a fixed fee and no fixed costs. Fixed costs and expended costs continue despite the production of many or fewer acquired, examples of gasoline costs. While variable cost is a cost influenced by the production obtained, the cost of labor costs (Widihastuti \& Rosyidah, 2018).

Fishermen's revenues determined based on revenue share and rarely accepted on a fixed wage or salary system. The granting of income through the revenue share system is the revenue received after deducting the cost of expenditure on operating time plus the cost of selling the fish catch (Irawan et al., 2016) (Sulastri, 2016).

\section{Production Theory}

Production is creating, generating, and making. Production activities will not be possible if no material allows the production process itself. To be able to do production, people need manpower, natural resources, capital in all its forms, as well as proficiency. All the elements called factors of production. So, all elements that support the business create value or effort enlarging the value of goods referred to as production factors (Esa \& Putra, 2016).

The concept of the Cobb Douglas function is an equation involving two or more variables, one independent variable and the other called independent variables. A common mathematical Model of the Cobb Douglas production function is the following (Mankiw, 2018):

$$
\mathrm{Q}=\mathrm{AL}^{\alpha} \mathrm{K}^{\beta}
$$

Description:

Q: Production output

A: Interceps (Efficiency parameters)

$\mathrm{K}$ : Input 1 (modal)

L: input 2 (labor)

$\alpha$ : Input elasticity 1 (capital)

$\beta: 2$ input elasticity (labour force)

How to acquire the Cobb Douglas production function can be obtained by making linear equations, so that it becomes (Christopher T.S. Ragan, 2019):

$$
\ln \mathrm{Q}=\ln \mathrm{A}+\alpha \ln \mathrm{K}+\beta \ln \mathrm{L}+\mu
$$

By stretching the function of the Cobb Douglas production is easily obtained efficiency parameters (A) and the elasticity of the input.

\section{Research Methods \\ Population and Sample}

The population is a generalized region consisting of objects or subjects that have specific quantities and characteristics defined by researchers to learn and then withdraw (Prof. Dr. Suryana, 2012). Therefore, the population of this research is a fisherman in East Belitung and Central Bangka District. 
Samples are the number and characteristics owned by the population. When the population is large then researchers are unlikely to learn all that exists in the population due to limited funds, energy and time, so that the samples are taken from the population representing the research objectives (Bateman et al., 2017). Hence the determination of the samples in this study using Yamane, Isaac and Michael formulas are:

$$
\mathrm{n}=\frac{N}{1+N(e)^{2}} \ldots \ldots \ldots \ldots \ldots \ldots
$$

Description:

$\mathrm{n}=$ Number of samples required

$\mathrm{N}=$ Population number

$\mathrm{e}=$ Error Rate sample (sampling error), usually set to $1 \%$ or $5 \%$

Then samples of fishermen acquired for East Belitung district taken as many as 181 respondents with the formula:

$$
\mathrm{n}=\frac{300}{1,825}=181
$$

Hence samples of fishermen acquired for in central Bangka District were taken as many as 57 respondents with the formula:

$$
\mathrm{n}=\frac{66}{1,665}=57 \text {. }
$$

\section{Data source}

This research uses primary data, in the form of interviews and dissemination of the questionnaire to fishermen. Using quantitative analysis with the path analysis method and explained in detail. Path analysis illustrates the pattern of causal relationships between a number of pees, and the analysis of this pathway has the power to print or test the causal that is to be reduced and not to lower the causal theory (Mordukhovich \& Nam, 2013). The respondent's profile can be seen in

\begin{tabular}{|c|c|c|c|c|c|c|c|}
\hline \multirow[b]{2}{*}{ Variabel } & \multirow[b]{2}{*}{ Component } & \multicolumn{2}{|c|}{$\begin{array}{c}\text { East } \\
\text { Belitung } \\
\text { Disrict }\end{array}$} & \multicolumn{2}{|c|}{$\begin{array}{l}\text { Central } \\
\text { Bangka } \\
\text { District }\end{array}$} & \multicolumn{2}{|c|}{ Total } \\
\hline & & $\mathbf{N}$ & $\%$ & $\mathbf{N}$ & $\%$ & $\mathbf{N}$ & $\%$ \\
\hline \multirow{4}{*}{$\begin{array}{l}\text { Types of } \\
\text { fishermen }\end{array}$} & Crew's & 78 & $43 \%$ & 0 & $0 \%$ & 78 & $33 \%$ \\
\hline & Fisherman motorboat & 65 & $36 \%$ & 27 & $47 \%$ & 92 & $39 \%$ \\
\hline & Traditional fisherman & 38 & $21 \%$ & 30 & $53 \%$ & 68 & $28 \%$ \\
\hline & 20-29 years old & 8 & $4 \%$ & 13 & $23 \%$ & 21 & $9 \%$ \\
\hline \multirow[t]{5}{*}{ Age } & 30-39 years old & 63 & $35 \%$ & 15 & $26 \%$ & 78 & $33 \%$ \\
\hline & 40-49 years old & 87 & $48 \%$ & 12 & $21 \%$ & 99 & $42 \%$ \\
\hline & $50-59$ years old & 21 & $12 \%$ & 15 & $26 \%$ & 36 & $15 \%$ \\
\hline & $>60$ years old & 2 & $1 \%$ & 2 & $4 \%$ & 4 & $2 \%$ \\
\hline & No School & 27 & $15 \%$ & 27 & $47 \%$ & 54 & $23 \%$ \\
\hline \multirow[t]{4}{*}{ Education } & Elementary School & 108 & $60 \%$ & 23 & $40 \%$ & 131 & $55 \%$ \\
\hline & Junior High School & 36 & $20 \%$ & 2 & $4 \%$ & 38 & $16 \%$ \\
\hline & Senior High School & 10 & $6 \%$ & 4 & $7 \%$ & 14 & $6 \%$ \\
\hline & Diploma Degree & 0 & $0 \%$ & 1 & $2 \%$ & 1 & $0 \%$ \\
\hline
\end{tabular}
table 2 .

Table 2. Respondents profile 


\begin{tabular}{clcccccc}
\multirow{3}{*}{ Experience } & $4-10$ years & 5 & $3 \%$ & 13 & $23 \%$ & 18 & $8 \%$ \\
& $10-15$ years & 11 & $6 \%$ & 7 & $12 \%$ & 18 & $8 \%$ \\
& $15-20$ years & 39 & $22 \%$ & 7 & $12 \%$ & 46 & $19 \%$ \\
& $20-25$ years & 62 & $34 \%$ & 4 & $7 \%$ & 66 & $28 \%$ \\
& $25-30$ years & 27 & $15 \%$ & 7 & $12 \%$ & 34 & $14 \%$ \\
& $30>$ years & 37 & $20 \%$ & 19 & $33 \%$ & 56 & $24 \%$ \\
\hline
\end{tabular}

Source: data processed, 2019

Based on the data in table 2 that the most numerous fishermen using a motorboat of 39 percent. The age of a fisherman who is the most widely aged $40-49$ years is 42 percent because this age is a productive life in the work. While fishermandominated education is an elementary school of 55 percent with the most experience for 20-25 years of 28 percent.

\section{Framework}

The framework of the thought in the research can be seen on the figure 2 .

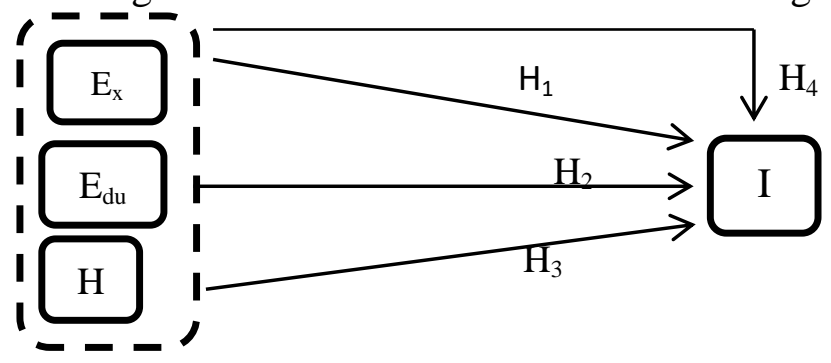

Source: data processed, 2019

Figure 2. Framework of The Research

Based on theoretical foundation and results - the results of previous research, the hypothesis in this study is:

H1 : Fishing incomes have significant effect on experience.

$\mathrm{H} 2$ : Fishing incomes have significant effect on education.

H3 : Fishing incomes significantly affect the hours.

H4: Fishing incomes have significant effect on educational experience and working hours.

Then made analysis of the path based on the research topic as follows:

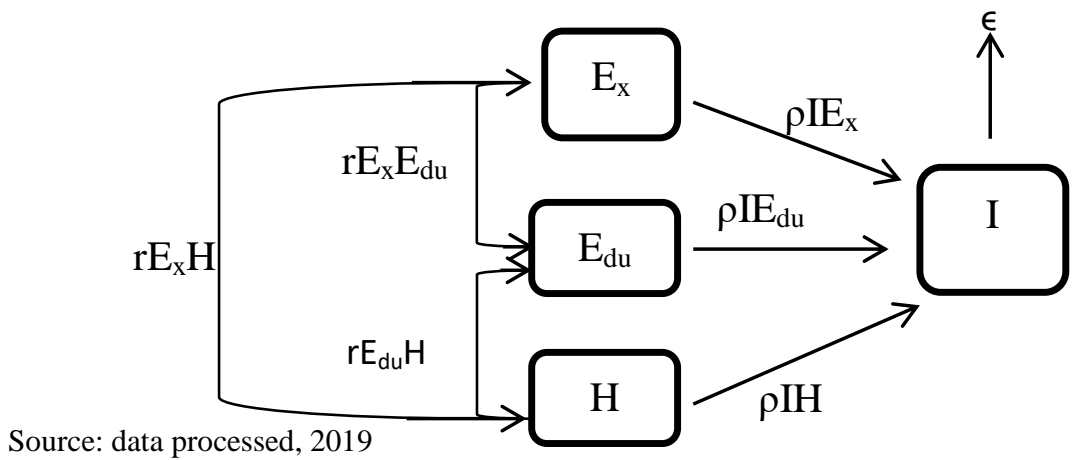

Figure 3. Path analysis of this research

Description: 
$\rho \mathrm{WE}_{\mathrm{x}}$ : Pathway coefficient influences experience on incomes.

$\rho \mathrm{WE}_{\mathrm{du}}$ : Pathway coefficient influences education on incomes.

$\rho \mathrm{WH}$ : Pathway coefficient influences hour on incomes.

$\mathrm{rE}_{\mathrm{x}} \mathrm{E}_{\mathrm{du}}$ : Pathway coefficient influences experience on education.

$\mathrm{rE}_{\mathrm{du}} \mathrm{H}$ : Pathway coefficient influences education on hours.

$\mathrm{rE}_{\mathrm{x}} \mathrm{H}$ : Pathway coefficient influences experience on hours.

\section{Analytical methods}

The structure of the multiple linear regression model consists of independent and dependent variables, in the study the dependent variable is incomes and the independent variable consists of experience, education and working hours of fishermen with the following formula:

$$
\mathrm{I}=\mathrm{b}_{0}+\mathrm{b}_{1} \mathrm{E}_{\mathrm{x}}+\mathrm{b}_{2} \mathrm{E}_{\mathrm{du}}+\mathrm{b}_{3} \mathrm{H}+\epsilon
$$

The assumption used in linear regression is (Gujarati, 2004):

1. $E E\left(e_{i} \mid X_{i}\right)=0$ Which means the expected value of the $e_{i}$ depending on the $X_{i}$ certain is zero.

2. $\operatorname{Cov}($ ei,ej $)=E[e i-E(e i)][e i-E(e j)]=E(e i e j)=0$ dengan $i \neq j$ Which means the absence of sequential correlation or no autocorrelation.

3. $\operatorname{Var}(\mathrm{ei} \mid \mathrm{Xi})=\mathrm{E}[\mathrm{ei}-\mathrm{E}(\mathrm{ei})] 2=\mathrm{E}(\mathrm{ei} 2)=\sigma 2$ Which means the homoskesdastisity or the same variant.

Path analysis methods have direct and indirect influences. Direct influence is the direction of the relationship between two direct variables without passing another variable, while indirect influences must pass another variable. The magnitude of direct influence between variables by using a standardized coefficient of beta or regression coefficient. While the amount of indirect influence in the path analysis is by multiplying the direct coefficient of variable effect free to bound variables. The basic model structure of path analysis is:

$$
\begin{aligned}
& \mathrm{Y}=\beta \quad \mathrm{Y}+\mu \quad \mathrm{X}+\mathrm{e} \\
& \begin{array}{llllll}
\rho x_{1} & \rho x \rho & \rho x_{1} & \rho x q & q^{2} & \rho x_{1}
\end{array}
\end{aligned}
$$

Assumptions of path analysis according to Cleff (2019):

1. The relationships between variables in the model are linear, causal, and additive.

2. All errors are not related or correlated with others in the model.

3. There is only a one-way causal relationship in the model.

4. Variables are measured using interval scales.

5. The observed variables are assumed to be measured without errors.

6. The model used is assumed or specified precisely, i.e. put all causes into the model

So based on the basic formula of path analysis and assumptions, the path analysis model in this research is:

$$
\mathrm{I}={ }_{\rho \mathrm{IEx}} \mathrm{E}_{\mathrm{x}}+{ }_{\rho \mathrm{IEdu}} \mathrm{E}_{\mathrm{du}}+{ }_{\rho \mathrm{IH}} \mathrm{H}+\epsilon
$$

Description:

I $\quad=$ Income

Ex $\quad=$ Experience

Edu $=$ Education 
$\mathrm{H} \quad=$ Hour

\section{Results}

\section{Testing requirement Analysis}

Data must be tested for normality, linearity, and homogeneity to proceed to data analysis. The normality test is done using the Skewness ratio and Kurtosis ratio. The normality test results can be seen in the table 3 .

Table 3. Normality Test Using The Skewness and Kurtosis Ratio

\begin{tabular}{lccc}
\hline \multicolumn{1}{c}{ Variabel } & The Skewness ratio & The Kurtosis ratio & Conclusion \\
\hline Income & $0,918($ at -2 to +2$)$ & $0,692($ at -2 to +2$)$ & Normal data distribution \\
Experience & $-0,328($ at -2 to +2$)$ & $-0,712($ at -2 to +2$)$ & Normal data distribution \\
Education & $0,958($ at- 2 to +2$)$ & $1,615($ at -2 to +2$)$ & Normal data distribution \\
Hour & $-0,678($ at -2 to +2$)$ & $-0,782($ at -2 to +2$)$ & Normal data distribution \\
\hline Source: data processed, 2019 & &
\end{tabular}

Multicholinerity is the presence of significant linear relationships between independent variables in regression. To detect a multicholinerity in a regression model can be measured by the value Variance Inflation Factor (VIF) $>10$ and if VIF $<10$ It means free from multicolinierity. The multicholinerity test results can be seen in the table 4 .

Table 4. Multicholinerity Test

\begin{tabular}{lcc}
\hline & Variabel & \multicolumn{2}{c}{ Collinearity Statistics } \\
\cline { 2 - 3 } & Tolerance & VIF \\
\hline (Constant) & & \\
Experience & 0,988 & 1.012 \\
Education & 0,984 & 1.016 \\
Hour & 0,993 & 1.007 \\
\hline Source: data processed, 2019 & &
\end{tabular}

Calculates the correlation value between variables by using the formula:

$$
\begin{gathered}
\mathrm{r}_{\mathrm{Xy}}=\frac{\left(\mathrm{n} \sum_{i=1}^{n} X i Y i\right)-\left(\mathrm{n} \sum_{i=1}^{n} X i\right)\left(\mathrm{n} \sum_{i=1}^{n} Y i\right)}{\sqrt{\left\{\left(\mathrm{n} \sum_{i=1}^{n} X i\right)^{2}-\left(\sum_{i=1}^{n} X i\right)^{2}\right\}\left\{\left(\mathrm{n} \sum_{i=1}^{n} Y i\right)^{2}-\left(\sum_{i=1}^{n} Y i\right)^{2}\right\}}} \text { with } \mathrm{i}= \\
1,2,3,4, \ldots \ldots, 160 \ldots \ldots \ldots \ldots \ldots(10)
\end{gathered}
$$

So that acquired matric correlation between variables as follows:

$R=\left|\begin{array}{cccc}1 & 0,137 & 0,062 & 0,150 \\ 0,137 & 1 & 0,-100 & 0,039 \\ 0,062 & -0,100 & 1 & 0,72 \\ 0,150 & 0,39 & 0,72 & 1\end{array}\right|$

\section{Equation of structure and magnitude of influence}

Calculation of influence coefficient value (b) variable and path coefficient test as follows: 
Table 5. Calculation result and test coefficient of path

\begin{tabular}{|l|l|l|}
\hline Path & Beta $(\boldsymbol{\beta})$ & Sig \\
\hline$\rho \mathrm{IEx}$ & 0,138 & 0,032 \\
\hline$\rho \mathrm{IEdu}$ & 0,065 & 0,310 \\
\hline$\rho \mathrm{IH}$ & 0,139 & 0,31 \\
\hline
\end{tabular}

Source: data processed, 2019

The regression results in table 4 show that the level of experience has a sig value. $0.032<0.05$ and the beta value coefficient of 0.138 illustrates the level of experience has a positive and significant effect on fishermen's incomes. Education has a sig. $0.310>0.05$ and the beta coefficient value 0.065 indicates that education has a positive but not significant effect on fishermen's incomes. Whereas work hours have a sig value. $0.031<0.05$ and the beta coefficient value 0.139 shows that fishermen's working hours have a positive and significant influence on fishermen's incomes.

Model Summary Results of $\mathrm{R}$ Square or $\mathrm{R}^{2}$ or coefficient of determination is 0551. Manually $R$ Square can be calculated by changing the line coefficient matrix C, I and I become matrix of rows and then by the column matrix Y, then the R Square is calculated through the path coefficient of another variable outside the model, $\rho$ Y1e with the formula:

$$
\rho \mathrm{Y}_{1} \mathrm{e}=\sqrt{(1-0,044)}=0,978
$$

Based on the result of the line coefficient and $\mathrm{R}^{2}$ coefficient of pathway, the result of path analysis can be explained in the following framework:

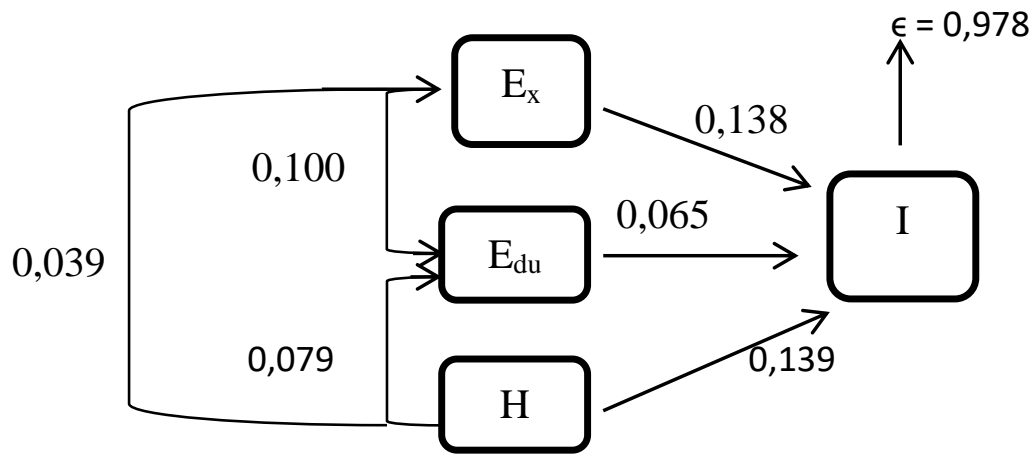

Source: data processed, 2019

Figure 4. Path analysis of the research result

\section{Hypothesis Testing}

\section{Pathway coefficient influences experience on incomes.}

The calculation of the path coefficient value, because there is only one exogenous variable $E_{x}$ and one endogenous variable $I$, the path coefficient is equal to the magnitude of the correlation coefficient between the two, 0.138 . In the suitability testing of the model, the result of F-count is 4.538, more than F-table of 2.643, then $\mathrm{H}_{0}$ is rejected. While the t-test of 2.153 is greater than the table of 1.969 then $\mathrm{H}_{0}$ is also rejected. That is, at a significance level of 5 percent there is the effect of experience on fishermen's incomes. 
The results of the path analysis between the experience of fishermen on the income level indicate that if a fisherman has the longest experience, the income level will be even higher. Based on research, the longest experience fishermen have is for 30 years. This experience can make fishermen more familiar with sea weather conditions, already have many crew members, have the capital, and even start to switch to marketing directly to the market because there are many relationships. The results of this study are the same as those found by Primyastanto et al. (2012) Abd. Rahim and Dwi Hastuti (2016) Ridha (2017).

\section{Pathway coefficient influences education on incomes.}

The calculation of the path coefficient value because there is only one exogenous variable $\mathrm{E}_{\mathrm{du}}$ and one endogenous variable $\mathrm{I}$, the path coefficient is equal to the magnitude of the correlation coefficient between the two, 0.065. In testing the suitability of the model obtained F-count value of 0.898 is smaller than F-table of 2.643 then $\mathrm{H}_{0}$ is accepted. While the t-test of 1.017 is smaller than the table of 1.969 then $\mathrm{H}_{0}$ is also accepted. That is, at a significance level of $5 \%$ there is no influence of fishermen education on fishermen's incomes.

Education is not a direct factor that causes an increase in fishermen's incomes. It is this fishermen's education affects the poverty level of fishermen because of the lack of awareness of fishermen to save and improve children's education. Fishermen are more likely to rely on middlemen to borrow money (Pancasasti, 2008) (Velentina, 2018) (Vibriyanti, 2019). Fishermen tend to spend more on the needs of buying cigarettes and gasoline, compared to saving for the needs of school children (Putri et al., 2018). Moreover, the average education owned by fishermen is an elementary school and some even do not go to school. Based on the results of research interviews, to become fishermen they do not need to have high education, and enough to study with parents who are also a fisherman.

\section{Pathway coefficient influences hour on incomes.}

Calculation of the path coefficient value because there is only one exogenous variable $\mathrm{H}$ and one endogenous variable $\mathrm{I}$, then the path coefficient is equal to the size of the correlation coefficient between the two, 0.139. In testing the suitability of the model obtained F-count value of 5.398 is greater than F-table of 2.643 then $\mathrm{H}_{0}$ rejected. While the t-test of 2.174 is greater than the table of 1.969 then $\mathrm{H}_{0}$ is also rejected. That is, at a significance level of 5 percent there is no effect on fishermen's working hours on fishermen's incomes.

The longer the fishermen are at sea, the more incomes they have (Azizi et al., 2017). Fishermen in Central Bangka District and East Belitung District begin to go to sea starting at 19.00 at night and come back again depending on the tides in the river mouth, sometimes at 05.00 sometimes 19.00 or 10.00 . The longest working hour is 240 hours or as long as 10 days and at least 24 hours. Fishermen who have been fishing for a long time are fishermen who have motorized vessels and crew, while fishermen who have been sailing for 24 hours are traditional fishermen. 


\section{Conclusion and Suggestion \\ Conclusion}

Based on the research results obtained by $\mathrm{H}_{0}$, fishermen's experience of incomes rejected and $\mathrm{H}_{1}$ accepted, meaning that experience is a factor of fishermen's income variability. Working hours are also a factor in the variability of fishermen's incomes because the results of processing the $\mathrm{H}_{0}$ path analysis assessment rejected and $\mathrm{H}_{1}$ accepted. Education is not a factor of fishermen's income variability because the assessment results obtained by $\mathrm{H}_{0}$ accepted and $\mathrm{H}_{1}$ rejected, meaning to get high incomes, fishermen do not need higher education.

\section{Suggestion}

Future research should measure the variability of fishermen's incomes using variables of the level of fish production, the amount of credit or debit, side income, and poverty of fishermen. Methods to measure this variability can use methods such as Micmac, then if you want to involve the government you can use Mactor, so that the root of the problem will be better known.

\section{Acknowledgement}

This research was conducted with the financing from the Ministry of Ristek Dikti through a research scheme of beginner (Penelitian Dosen Pemula/PDP) in 2019. The Output of the research is the publication on an accredited National Journal. Thanks to the Ministry of Ristek Dikti who has facilitated the implementation of this research and thanks to the majors, faculty and universities for support in the implementation of this research.

\section{References}

1. Azizi, A. A., Kumala Putri, E. I., \& Fahrudin, A. (2017). Analisis FaktorFaktor Yang Mempengaruhi Perubahan Pendapatan Nelayan Akibat Variabilitas Iklim. Jurnal Sosial Ekonomi Kelautan Dan Perikanan, 12(2), 225. https://doi.org/10.15578/jsekp.v12i2.5320

2. Bateman, B. W., Dunn, S. P., Emmett, R. B., Field, A. J., Hagemann, H., Hammond, J. D., Hebert, R. F., Hodgson, G. M., \& Kuiper, E. (2017). List of Contributors. List of Contributors. P019-P019. https://doi.org/10.1039/9781788010115-fp019

3. Christopher T.S. Ragan. (2019). Ragan Microeconomics, Sixteenth Canadian Edition. https://doi.org/10.1017/CBO9781107415324.004

4. Cleff, T. (2019). Applied Statistics and Multivariate Data Analysis for Business and Economics. In Applied Statistics and Multivariate Data Analysis for Business and Economics. https://doi.org/10.1007/978-3-03017767-6

5. Dwinda dahen, lovelly. (2016). Analisis Pendapatan Nelayan Pemilik Payang Di Kecamatan Koto Tangah Kota Padang. Economica, 5(1), 46-53. https://doi.org/10.22202/economica.2016.v5.i1.891

6. Esa, G., \& Putra, A. B. (2016). Analisis Faktor-FAktor yang Mempengaruhi Produksi dan Pendapatan Nelayan di Desa Batununggul Kecamatan Nusa Penida. E-Jurnal EP Unud, 8 [5], 1092-1121. 
7. Gujarati, D. N. (2004). Basic Econometrics (fourth edi).

8. Ioan, C., Ioan, G., \& Ioan, G. (2015). The Complete Theory of Cobb-Douglas Production Function. Acta Universitatis Danubius. OEconomica, 11(1), 74114.

9. Irawan, B., Suryana, A., Pasaribu, S. M., \& Syukur, M. (2016). Sistem Bagi Hasil dan Dampak Motorisasi Penangkapan Ikan Terhadap Pendapatan Nelayan di Langkat Sumatera Utara. Forum Penelitian Agro Ekonomi, 6(1), 26. https://doi.org/10.21082/fae.v6n1.1988.26-35

10. Juariyah, B. dan S. (2010). Jurnal Ekonomi \& Pendidikan, Volume 7 Nomor 1, April 2010. Jurnal Ekonomi \& Pendidikan, 7(April), 58-81.

11. Kesuma, A., Desy, P., \& Dalimunthe, Y. (2018). Analisa Teori Life Cycle pada Rumah Tangga Nelayan di Propinsi Kepulauan Bangka Belitung. 1.

12. Mankiw, N. G. (n.d.). Principles of Economics, 8th ed.

13. Marfirani, R., \& Adiatma, I. (2012). Pergeseran Mata Pencaharian Nelayan Tangkap Menjadi Nelayan Apung Di Desa Batu Belubang. Prosiding Seminar Nasional Pengelolaan Sumberdaya Alam Dan Lingkungan Semarang, 11 September 2012 Pergeseran, September, 105-114. ergeseran Mata Pencaharian\%0ANelayan Tangkap Menjadi Nelayan Apung Di Desa Batu Belubang

14. Nurprihatin, F., \& Tannady, H. (2017). Pengukuran Produktivitas Menggunakan Fungsi Cobb-Douglas Berdasarkan Jam Kerja Efektif. JIEMS (Journal of Industrial Engineering and Management Systems), 10(1). https://doi.org/10.30813/jiems.v10i1.36

15. Pancasasti, R. (2008). Peluang Kemiskinan Nelayan Tradisional ( Studi Kasus: Rumahtangga Nelayan Tradisional Di Kecamatan Kasemen Kabupaten Serang Propinsi Banten ) RANTHY PANCASASTI.

16. Pratama, D. S., Gumilar, I., \& Maulina, I. (2012). Analisis pendapatan nelayan tradisional pancing ulur di Kecamatan Manggar, Kabupaten Belitung Timur. Jurnal Perikanan Dan Kelautan, 3(3), 107-116.

17. Primyastanto, M., Efani, A., \& Muhammad, S. (2012). Kajian Ekonomi Rumah Tangga Nelayan Payang di Selat Madura, Jawa Timur. Jurnal Wacana, 15 (2)(2), 12-19.

18. Rahim, Abd., \& Dwi Hastuti, D. R. (2016). Determinan Pendapatan Nelayan Tangkap Tradisional Wilayah Pesisir Barat Kabupaten Barru. Jurnal Sosial Ekonomi Kelautan Dan Perikanan, $11(1), \quad 75$. https://doi.org/10.15578/jsekp.v11i1.3173

19. Rahim, Abdul. (2017). Analisis Pendapatan Usaha Tangkap Nelayan Dan Faktor-Faktor Yang Mempengaruhinya Di Wilayah Pesisir Pantai Sulawesi Selatan. Jurnal Sosial Ekonomi Kelautan Dan Perikanan, 6(2), 235. https://doi.org/10.15578/jsekp.v6i2.5776

20. Rahmawati, N. (2017). Pengaruh pendapatan terhadap tabungan pada masyarakat nelayan di desa kuala secapah kecamatan mempawah hilir.

21. Ridha, A. (2017). Analisis Faktor-Faktor yang Mempengaruhi Pendapatan Nelayan di Kecamatan Idi Rayeuk. Jurnal Samudra Ekonomi Dan Bisnis, 8(1), 646-652. https://doi.org/10.33059/jseb.v8i1.205

22. Sulastri, A. H. S. R. (2016). Analisis Faktor-Faktor Yang Mempengaruhi Pendapatan Nelayan Di Kabupaten Aceh Besar. Jurnal Ilmu Ekonomi: Program Pascasarjana Unsyiah, 2(3), 84-93. 
23. Suryana, Ms. (2012). Metodologi Penelitian: Metodologi Penelitian Model Prakatis Penelitian Kuantitatif dan Kualitatif. Universitas Pendidikan Indonesia, 1-243. https://doi.org/10.1007/s13398-014-0173-7.2

24. Utara, J. (2016). Tingkat Kesejahteraan Nelayan Skala Kecil Di Kabupaten Indramayu Welfare Level of Small Scale Fishers Based on Sustainable Livelihood Approach in Indramayu District. 021, 29-43.

25. Velentina, R. A. (2018). Kebijakan Pembiayaan Bagi Nelayan Tradisional. Masalah-Masalah Hukum, 47(3),

184. https://doi.org/10.14710/mmh.47.3.2018.184-197

26. Vibriyanti, D. (2019). Analisis Deskriptif Faktor Sosial Ekonomi Yang Mempengaruhi Pendapatan Rumah Tangga Nelayan Tangkap (Studi Kasus: Kota Kendari). Jurnal Kebijakan Sosial Ekonomi Kelautan Dan Perikanan, 9(1), 69. https://doi.org/10.15578/jksekp.v9i1.7440

27. Widihastuti, R., \& Rosyidah, L. (2018). Sistem Bagi Hasil Pada Usaha Perikanan Tangkap Di Kepulauan Aru. Jurnal Kebijakan Sosial Ekonomi Kelautan Dan Perikanan, 8(1), 63. https://doi.org/10.15578/jksekp.v8i1.6859 